Bangladesh J. Bot. 49(1): 147-158, 2020 (March)

\title{
ANALYSIS OF GENETIC DIVERSITY IN OILSEED BRASSICA GERMPLASM THROUGH ISSR MARKERS AND ISOZYME PROFILING
}

\author{
Madhury Paul ${ }^{1}$, Tahmina Islam, Mi Hoque and RH Sarker* \\ Plant Breeding \& Biotechnology Laboratory, Department of Botany, \\ University of Dhaka, Dhaka-1000, Bangladesh
}

Keywords: Brassica, Genetic diversity, ISSR, Polymorphism, Genetic distance, Isozyme

\begin{abstract}
Eleven Brassica germplasm were characterized through the application of 12 oligonucleotide Inter Simple Sequence Repeat (ISSR) primers. A total 1248 bands were amplified through polymorphic chain reaction and were visualized by agarose gel electrophoresis. Among the amplified marker bands $71.47 \%$ were polymorphic in nature and 352 bands were found to be monomorphic. The polymorphic bands of the amplified DNAs mostly ranged between $110 \mathrm{bp}$ and $3 \mathrm{~kb}$. Genetic distance among the germplasm ranged between 0.0468 and 0.7189 . Moreover, three isozyme systems such as esterase, acid phosphatase and peroxidase were analyzed for allozyme variability that detected distinct 93 isozyme loci of which nearly $61.9 \%$ were polymorphic. Two dendrograms were constructed based on the ISSR profiling and isozyme data obtained through electrophoresis to find out the relatedness and phylogenetic relationship among the investigating Brassica germplasm. The clusters of the phylogenetic tree revealed 4 distinct groups of Brassica based upon their ISSR banding patterns and isozyme analysis. Nei's genetic distance analysis provided strong information about the existence of variability among the germplasm of Brassica. All the germplasm was found to be clustered according to their respective species. Brassica carinata (Ethiopian mustard) showed individuality from all the germplasm studied and made a different branch in the phylogenetic tree suggesting its diverse origin. From the clustering pattern and genetic relationship obtained with ISSR markers and isozyme analysis, breeders can successfully identify the diverse germplasm from different cluster and use them in their future breeding program.
\end{abstract}

\section{Introduction}

Brassica is one of the major crop genera in the family Brassicaceae (syn. Cruciferae). The genus is remarkable for containing a large number of important vegetables to oilseed and condiment crops than any other genus. Brassica is the second largest oilseed crop after soybean in the world (Raymer 2002, FAO 2010). Brassica oil contains many mono- and polyunsaturated fatty acids and a few harmful saturated fatty acids which make it nutritionally superior to most other edible oils (Agnihotri et al. 2007). Oilseed Brassica collectively contribute about 15\% of the world's total supply of vegetable oils and became the third-leading source of edible oil in the world after soybean and palm (McVetty et al. 2016). Indian mustard (Brassica juncea L.), rapeseed (Brassica campestris L. syn Brassica rapa L.), Brassica napus L. are important oil yielding crops in Bangladesh. Bangladesh Agricultural Research Institute (BARI) and Bangladesh Institute of Nuclear Agriculture (BINA) have already developed several varieties of Brassica in Bangladesh using efficient breeding techniques. But there are some problems associated with this crop such as unsynchronized maturity, pest and disease invasions, effect of abiotic stress like salinity and drought, etc. It may be pointed here that Brassica carinata constitutes an interesting alternative to diesel fuel in less-favored regions of the world (Dorado et al. 2004). It has been introduced into and field-tested for biofuel production in Canada (Marillia et al. 2014), India

\footnotetext{
*Author for correspondence: <rhsarker2000@yahoo.co.uk>. ${ }^{1}$ Department of Botany, Jagannath University,
} Dhaka-1100, Bangladesh. 
(Malik 1990), Italy (Bozzini et al. 2007), Pakistan (Zada et al. 2013) and Spain (Velasco et al. 2003). Acute shortage of edible oil has been prevailing in Bangladesh during last several decades. For proper improvement of Brassica, it is important to investigate the variability of the existing germplasm as well as to introduce some new germplasm those are superior in qualities.

Genetic variability in respect to genetic diversity is the prerequisite for the crop improvement through selection of desired progenies. Molecular markers allow the identification and characterization of plant genotypes through direct access to hereditary material (Ismail et al. 2016). Several genetic or phylogenetic relationships have been proposed for different taxas within $B$. rapa, based on morphology, geographical distribution, isozymes and different molecular markers (Zhao et al. 2005). Molecular markers are more effective to detect the variability in Indian mustard (Singh et al. 2013). Analysis by molecular markers help in choosing parental types for mapping populations, marker assisted selections and back crossing schemes and thus diversity studies conducted using various markers help the breeders to improve crop species.

Several types of molecular markers such as (Restriction Fragment Length Polymorphism (RFLP), Random Amplified Polymorphic DNA (RAPD), Amplified Fragment Length Polymorphism (AFLP), Simple Sequence Repeat (SSR), etc. are available for evaluating the extent of genetic variation in plants. Inter Simple Sequence Repeat (ISSR) markers have been proposed as a new source of genetic markers that are inherited in Mendelian fashion and are scored as dominant markers. It is a PCR-based marker and its genomic sequence lying between adjacent microsatellites (SSRs) (Zietkiewicz et al. 1994). These markers have been developed since 1994 and got acceptability for its low cost and less laborious but with high reliability (Zietkiewicz et al. 1994). The role of ISSR as phylogenetic markers to investigate evolutionary divergence among plants has been well established (Panda et al. 2002, Ghariani et al. 2003). Available literature indicated that there is no report on using ISSR markers for the diversity analysis of Brassica germplasm obtained in Bangladesh.

Isozymes are also considered as biochemical markers used as a powerful tool both in characterization of cultivar and in genetic and phylogenetic studies for many crop species (Tanksley and Orton 1983). The chances of correct cultivar identification are highly possible through isozyme electrophoresis (Ivy et al. 2010). These techniques are efficiently used for genetics, systematics and plant breeding, particularly in Brassica germplasm because of their high level of polymorphism (Chevre et al. 1991). In this study, isozyme data have also used for validation of the ISSR information for understanding the relationship among the Brassica germplasm.

Therefore, in the present investigation ISSR fingerprinting and isozyme data were considered to examine the genetic variability and to find out the genetic relationship among the studied Brassica germplasm. The potentiality of the germplasm was evaluated for their utilization in strengthening Brassica breeding programs.

\section{Materials and Methods}

All the 11 germplasm (Table 1) used in this study were collected from Oil Seed Division of Bangladesh Agricultural Research Institute (BARI), Joydebpur, Gazipur and Bangladesh Institute of Nuclear Agriculture (BINA), Mymensingh, except Brassica carinata which was obtained from Advanced Chemical Industries (ACI), Bangladesh. The materials were maintained in the Plant Breeding and Biotechnology Laboratory, Department of Botany, University of Dhaka.

Genomic DNA of all 11 Brassica germplasm was extracted using fresh and young leaves collected from 25 days old seedlings those were grown in the net house of the Department of Botany, University of Dhaka. Extraction of genomic DNA by CTAB (cetyltrimethylammonium 
bromide) method (Doyle and Doyle 1990) was carried with little modification. For this purpose, young and fresh leaves were washed in distilled water and ethanol and dried on fresh tissue paper to remove spores of microorganisms and any other source of foreign DNA. $400 \mathrm{mg}$ leaf tissue were taken in liquid nitrogen and grinded to fine powder followed by addition of $1.6 \mathrm{ml}$ extraction buffer (3\% CTAB; $1.4 \mathrm{M} \mathrm{NaCl} ; 100 \mathrm{mM}$ tris-HCl, pH 8.0; $20 \mathrm{mM}$ EDTA, pH 8.0 and $0.2 \%$ mercaptoethanol). The homogenous paste then transferred to an Eppendorf tube $(2.0 \mathrm{ml})$ and incubated at $60^{\circ} \mathrm{C}$ in a water bath for $30 \mathrm{~min}$. The samples were centrifuged at $13,000 \mathrm{rpm}$ for 10 $\min$ at $4^{\circ} \mathrm{C}$ then equal volume of chloroform: Isoamyl alcohol $(24: 1)$ was added with the supernatants and centrifuged the tubes at $13,000 \mathrm{rpm}$ for $10 \mathrm{~min}$. The supernatant with $2 / 3$ volume chilled isopropanol was kept overnight at $-20^{\circ} \mathrm{C}$ to precipitate the DNA. The supernatants were discarded carefully after centrifuged for $10 \mathrm{~min}$ at 13,000 rpm and DNA pellet was collected. The pellet was washed with $70 \%$ ice-cold ethanol and air dried. The dried DNA was dissolved in $50 \mu \mathrm{l}$ of TE buffer and treated with RNase A for $30 \mathrm{~min}$ at $37^{\circ} \mathrm{C}$ and stored at $-20^{\circ} \mathrm{C}$.

Table 1. List of Brassica germplasm used for ISSR analysis and isozyme localization.

\begin{tabular}{lll}
\hline Sl. No. & Species & Variety \\
\hline 1 & Brassica napus & BARI Sarisha-13 \\
2 & B. juncea & BARI Sarisha-11 \\
3 & B. juncea & BARI Sarisha-16 \\
4 & B. campestris & Safal \\
5 & B. campestris & Agrani \\
6 & B. campestris & Binasarisha-6 \\
7 & B. campestris & BARI Sarisha-15 \\
8 & B. campestris & Tori -7 \\
9 & B. napus & BARI Sarisha-8 \\
10 & B. campestris & BARI Sarisha-14 \\
11 & B. carinata & - \\
\hline
\end{tabular}

Then DNA was quantified by fluorometer (Qubit ${ }^{\circledR}$ 2.0, Catalog No. Q32866). Original stock solution concentration of each DNA sample was adjusted to a unique concentration $(25 \mathrm{ng} / \mu \mathrm{l})$ for PCR amplification reaction. A total 12 oligonucleotide ISSR primer was used for PCR amplification (Table 2).

PCR amplification was performed in a $25 \mu \mathrm{l}$ reaction mixture containing $25 \mathrm{ng} / \mu \mathrm{l}$ of template DNA $(1 \mu \mathrm{l}), 2.5 \mu \mathrm{l} 10 \times$ buffer, $100 \mu \mathrm{M}$ dNTPs, $1 \mu \mathrm{M}$ primer, $1 \mathrm{U}$ Taq polymerase. PCR amplifications were performed in a thermal cycler (Applied Biosystems) with initial denaturation at $94^{\circ} \mathrm{C}$ for $3 \mathrm{~min}$ followed by 35 cycles of $30 \mathrm{sec}$ at $94^{\circ} \mathrm{C}, 1 \mathrm{~min}$ at the annealing temperature of 34 to $64^{\circ} \mathrm{C}$ (for different primers), 2 min elongation at $72^{\circ} \mathrm{C}$ and final extension at $72^{\circ} \mathrm{C}$ for $7 \mathrm{~min}$.

The amplified products were separated electrophoretically on $1.5 \%$ agarose gel with $1 \times \mathrm{TAE}$ buffer and ethidium bromide. Agarose gel electrophoresis was conducted in $1 \times$ TAE buffer at 90 $\mathrm{V}$ and $250 \mathrm{~mA}$ for $90 \mathrm{~min}$. When required either $1 \mathrm{~kb}$ plus or $1 \mathrm{~Kb}$ DNA ladder (GeneRuler ${ }^{\mathrm{TM}}$ ) was electrophoresed alongside the PCR amplified products. Gel was photographed using UV Transilluminator (Cleaver Scientific Ltd.). 
Genetic distances matrix (Nei 1972) was computed from frequencies of polymorphic markers to estimate genetic relationship among the studied 11 Brassica germplasm using UPGMA (Table 3). The dendrogram was constructed using the computer software "Popgene 32". The Nei's distance matrix (Nei 1972) was employed to estimate the genetic distances among the germplasm.

Table 2. List of ISSR primers and their nucleotide sequence with their $G+C$ content.

\begin{tabular}{llll}
\hline Sl. No. & Primer code & Primer sequence $\left(5^{\prime}-3{ }^{\prime}\right)$ & G + C content $(\%)$ \\
\hline 1 & HB_09 & GTGTGTGTGTGTGG & 57.14 \\
2 & HB_13 & GACGACGACGC & 72.73 \\
3 & UBC 812 & GAG AGA GAG AGA GAG AA & 47.059 \\
4 & UBC 816 & CAC ACA CAC ACA CAC AT & 47.059 \\
5 & UBC 818 & CAC ACA CAC ACA CAC AG & 52.94 \\
6 & UBC 835 & AGAGAGAGAGAGAGAGYC & 50.0 \\
7 & UBC 841 & GAG AGA GAG AGA GAG AYC & 50.0 \\
8 & UBC 843 & CTCTCTCTCTCTCTCTRA & 44.44 \\
9 & UBC 847 & CACACACACACACACARC & 50.0 \\
10 & UBC 857 & ACA CAC ACA CAC ACA CYG & 50.0 \\
11 & UBC 878 & GGA TGG ATG GAT GGA T & 50.0 \\
12 & UBC 889 & DBD ACA CAC ACA CAC AC & 41.176 \\
\hline
\end{tabular}

Table 3. Summary of Nei's genetic distances of 11 germplasm of Brassica.

\begin{tabular}{|c|c|c|c|c|c|c|c|c|c|c|c|}
\hline \multicolumn{2}{|c|}{$\begin{array}{ll}\text { Brassica } 1 \\
\text { Germ- } \\
\text { plasm }\end{array}$} & 2 & 3 & 4 & 5 & 6 & 7 & 8 & 9 & 10 & 11 \\
\hline 1 & 0 & & & & & & & & & & \\
\hline 2 & 0.5019 & 0 & & & & & & & & & \\
\hline 3 & 0.5647 & 0.0575 & 0 & & & & & & & & \\
\hline 4 & 0.5041 & 0.4234 & 0.4312 & 0 & & & & & & & \\
\hline 5 & 0.5210 & 0.4312 & 0.4312 & 0.0628 & 0 & & & & & & \\
\hline 6 & 0.5125 & 0.4312 & 0.4234 & 0.0792 & 0.0468 & 0 & & & & & \\
\hline 7 & 0.5558 & 0.4710 & 0.4792 & 0.1071 & 0.0958 & 0.1357 & 0 & & & & \\
\hline 8 & 0.4469 & 0.4629 & 0.4710 & 0.2726 & 0.2463 & 0.2270 & 0.2860 & 0 & & & \\
\hline 9 & 0.2018 & 0.5210 & 0.5125 & 0.4710 & 0.4710 & 0.4157 & 0.5210 & 0.4469 & 0 & & \\
\hline 10 & 0.4957 & 0.4469 & 0.4710 & 0.1592 & 0.1241 & 0.1652 & 0.1712 & 0.2659 & 0.5470 & 0 & \\
\hline 11 & 0.5919 & 0.5558 & 0.5647 & 0.6485 & 0.6881 & 0.6780 & 0.7085 & 0.7189 & 0.5041 & 0.6581 & 0 \\
\hline
\end{tabular}

Apart from ISSR profiling, three isozymes, namely esterase, acid phosphatase and peroxidase were used for further characterization of the Brassica germplasm. Proteins isolated from the Brassica leaves were used for enzyme localization following gel electrophoresis. For the preparation of protein samples fresh leaves were homogenized in a mortar and pestle on ice in 0.1 M phosphate buffer ( $\mathrm{pH} 7.0$ ) and centrifuged at 15,000 rpm for $12 \mathrm{~min}$. The supernatant was used as samples for the vertical polyacrylamide gel electrophoresis (PAGE) for isozymes analysis following the techniques of Majumder et al. (2012). After performing the gel electrophoreses, the 
gels were stained for three different isozyme systems and the staining solutions were prepared according to Johnson et al. (2012) for the detection of isozymes on the electrophoretic gels.

Esterase activity on the slab gel was detected according to the method of Arús and Orton (1983). At first $100 \mathrm{ml} 0.2 \mathrm{M}$ sodium phosphate buffer ( $\mathrm{pH} 7.0$ ) were prepared by mixing $39.0 \mathrm{ml}$ from Solution A $\left(0.2 \mathrm{M} \mathrm{NaH}_{2} \mathrm{PO}_{4} \cdot \mathrm{H}_{2} \mathrm{O}\right)$ and $61.0 \mathrm{ml}$ from Solution B $\left(0.2 \mathrm{M} \mathrm{Na}_{2} \mathrm{HPO}_{4} .7 \mathrm{H}_{2} \mathrm{O}\right)$. Then $30 \mathrm{mg}$ of $\alpha$-napthyl acetate dissolved in $1.0 \mathrm{ml}$ absolute alcohol and $50 \mathrm{mg}$ of Fast blue B salt was mixed with $100 \mathrm{ml} 0.2 \mathrm{M}$ sodium phosphate buffer. Peroxidase loci were detected by incubating the gel in $0.6 \mathrm{ml}$ acetic acid, $0.1 \mathrm{~g}$ benzidine and $1 \%$ hydrogen peroxide in $100 \mathrm{ml}$ solution. For acid phosphatase localization, the gel was incubated in $100 \mathrm{ml}$ solution containing $\alpha$-napthyl acid phosphate monosodium salt ( $100 \mathrm{mg}$ dissolved in $1 \mathrm{ml}$ acetone and $1 \mathrm{ml} \mathrm{H}_{2} \mathrm{O}$ ), Fast Garnet GBC salt $75 \mathrm{mg}, 10 \% \mathrm{MgCl}_{2} 0.5 \mathrm{ml}$ and $0.2 \mathrm{M}$ sodium acetate.

After the electrophoresis, the gels were incubated in the respective staining solutions at room temperature in the dark until the clear bands on the gels appeared. Following proper staining the gels were fixed with 7\% acetic acid solution for $30 \mathrm{~min}$ and then the gels were washed with distilled water and photographed using the gel documentation system. The pairing affinity was calculated among the Brassica germplasm accordingly. The dendrogram was constructed using the computer software "Popgene 32". Each band was considered as isozymic character and scored as ' 1 ' for presence and ' 0 ' for absence (Bimb et al. 2004). The presence or absence of a certain isozymatic band was considered as a differentiating feature (Majumder et al. 2012). Zymogram was prepared and zymotypic frequencies were calculated.

\section{Results and Discussion}

ISSR analysis of the 11 germplasm of Brassica spp. using the 12 selected ISSR primers generated a total of 1248 bands of which $71.47 \%$ were polymorphic (Table 4). The mean number of loci per primer was 16.33 . Results indicated the presence of wide genetic variability as a result of the high polymorphism among the studied germplasm of Brassica. In all the 11 Brassica germplasm, 12 primers (Table 2) produced 1248 bands. Primarily, genetic distances matrix was prepared among all the germplasm. Genetic variance among the 11 germplasm of Brassica ranged in between 0.0468 and 0.7189 .

In all the 11 Brassica germplasm, 12 primers produced 1248 bands: 59 from HB_09, 216 from HB_13, 92 from UBC 812, 71 from UBC 816, 39 from UBC 818, 115 from UBC 835, 140 from UBC 841, 91 from UBC 843, 43 from UBC 847, 151 from UBC 857, 73 from UBC 878 and 158 from UBC 889 (Fig. 1). This high level of polymorphism could be attributed to the location of those germplasm in different regions and/or their pedigree information. Also, higher number of bands for each primer indicates the existence of larger genetic diversity among the germplasm under investigation (Agrama and Tuinstra 2003). Primers with higher polymorphic bands are more efficient in studying genetic diversity and discrimination of the germplasm (Moghaddam et al. 2009).

In the present investigation, by using ISSR primers polymorphism has been found $71.47 \%$ (Table 4) in different germplasm of Brassica. In different plants using ISSR markers, a diverse level of polymorphisms has been reported such as, in case of wheat 84.8\% (Abou-Dief et al. 2013), litchi 72.7\% (Long et al. 2015), chickpea 68\% (Pakseresht et al. 2013), etc. Average number of bands reported was 3.0 (Ishida et al. 2000), 5.54 (Shiran et al. 2004), 8.6 (Kimura et al. 2000) and 9.6 (Sandip et al. 1999).

Knowledge of genetic similarity (distance) between germplasm and among individuals or populations is useful in a breeding program because it permits organization of germplasm and provides more efficient sampling of germplasm to cross for the development of populations (Afiah 
et al. 2007). In this study, the UPGMA analysis dendrograms and distance matrix coefficients revealed good relationships between some cultivars (Table 3). Primarily, genetic distance matrix was calculated according to Nei (1972) for all the 11 Brassica germplasm considering ISSR banding pattern (Table 3).
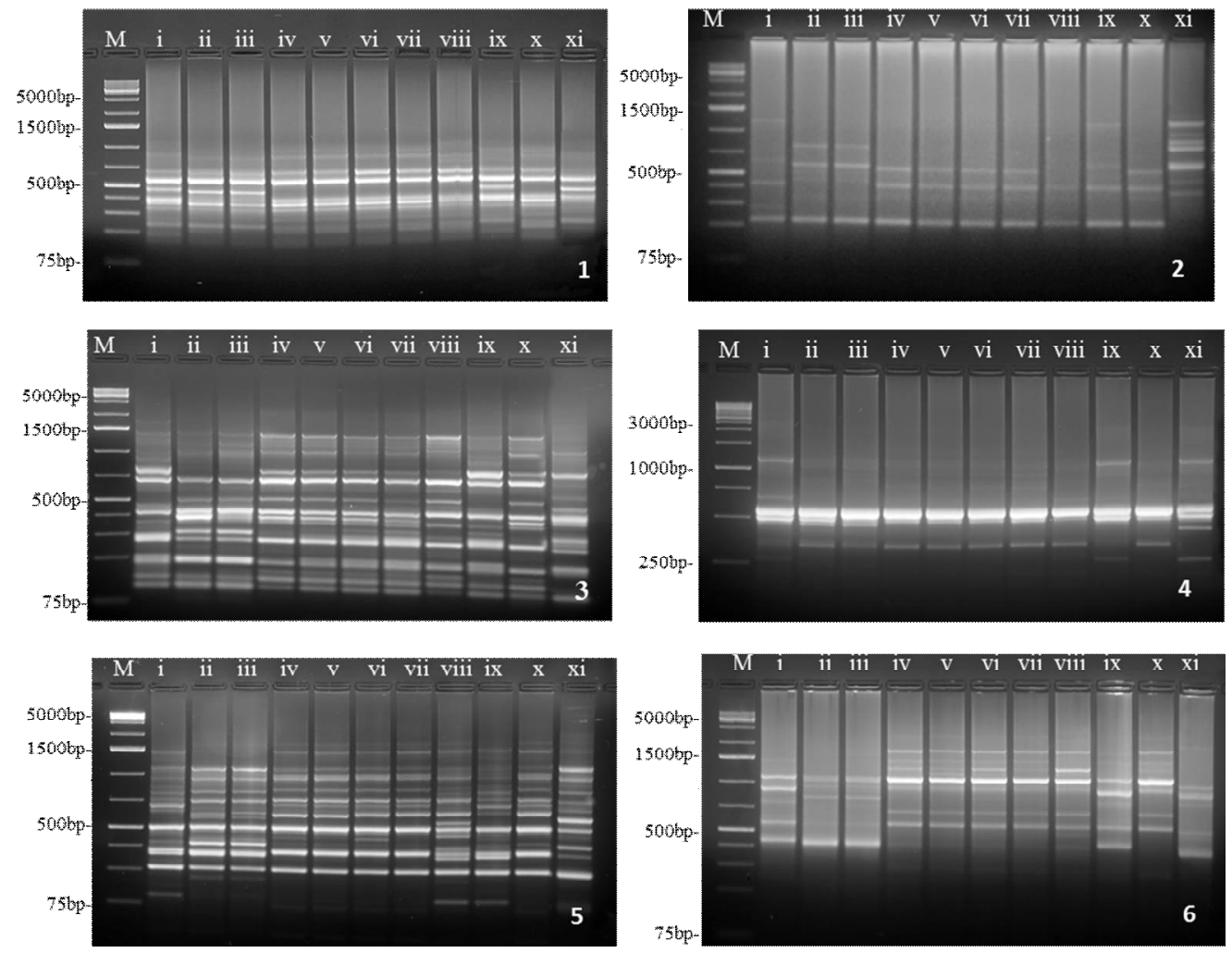

Fig. 1. ISSR profiles of the 11 Brassica germplasm: 1 - Amplification of bands with UBC 816 primer. Lane-M Ladder $(1 \mathrm{~Kb}+)$ and lane $\mathrm{i}-\mathrm{xi}$, amplified DNA of (i) Brassica napus var. BARI-13, (ii) Brassica juncea var. BARI-11, (iii) Brassica juncea var. BARI-16, (iv) Brassica campestris var. Safal, (v) Brassica campestris var. Agrani, (vi) Brassica campestris var. Bina-6 (vii) Brassica campestris var. BARI-15, (viii) Brassica campestris var. Tori-7, (ix) Brassica napus var. BARI-8 (x) Brassica campestris var. BARI-14 (xi) Brassica carinata, respectively. 2 - Same as (a) but with UBC 818 primer and $1 \mathrm{~Kb}$ + Ladder.; 3 - Same as (a) but with UBC 841 primer and $1 \mathrm{~Kb}+$ Ladder.; 4 Same as (a) but with UBC 847 primer and $1 \mathrm{~Kb}$ Ladder.; 5 - Same as (a) but with UBC 857 primer and $1 \mathrm{~Kb}+$ Ladder; 6 - Same as (a) but with UBC 878 primer and $1 \mathrm{~Kb}$ Ladder.

Genetic variation among the germplasm usually reveal by the genetic distances matrix. In this study, the lowest genetic distance was found between Agrani and Bina-6 (0.0468). On the other hand, the highest genetic distance was found between Tori-7 and Brassica carinata (0.7189). Relatively high genetic distance observed between BARI-13 and BARI-16 (0.5647), BARI- 13 and Agrani (0.5210), BARI-13 and Bina-6 (0.5125), BARI-13 and BARI-15 (0.5558), BARI-8 and BARI-15 (0.5210), BARI-14 and BARI-15 (0.5470). All the modern varieties released by BARI and BINA showed moderate level of genetic distance, which ranged from 0.0468 to 0.5647 . But each of them showed high level of genetic distance with Brassica carinata which ranged from 0.5042 to 0.7089 . 
The phylogenetic relationships among 11 Brassica germplasm were analyzed by UPGMA method (Fig. 2). The cluster result indicated that ISSR markers could distinguish all the germplasm. Grouping of the Brassica germplasm into each cluster or branch correlated with similarities in their ISSR DNA patterns. For example, the Brassica germplasm that produced the same DNA banding patterns were also recognized as being similar from phylogenetic analysis. Those germplasm belonged to the same cluster has been presented in the resulting phylogenetic tree (Fig. 2).

Table 4. Levels of polymorphism within Brassica germplasm.

\begin{tabular}{lcccc}
\hline Germplasm & $\begin{array}{c}\text { No. of total } \\
\text { bands }\end{array}$ & $\begin{array}{c}\text { No. of poly- } \\
\text { morphic } \\
\text { bands }\end{array}$ & $\begin{array}{c}\text { \% of poly- } \\
\text { morphism } \\
\text { exists in Brassica } \\
\text { germplasm }\end{array}$ & $\begin{array}{c}\text { Av. \% of } \\
\text { polymorphism } \\
\text { exists in Brassica } \\
\text { germplasm }\end{array}$ \\
\hline Brassica napus var. BARI-13 & 112 & 80 & 71.14 & \\
B. juncea var. BARI-11 & 117 & 85 & 72.65 & \\
B. juncea var. BARI-16 & 115 & 83 & 72.17 & \\
B. campestris var. Safal & 115 & 83 & 72.17 & \\
B. campestris var. Agrani & 112 & 80 & 71.43 & \\
B. campestris var. Bina-6 & 113 & 81 & 71.68 & 71.47 \\
B. campestris var. BARI-15 & 116 & 86 & 71.41 & \\
B. campestris var. Tori-7 & 116 & 84 & 71.41 & \\
B. napus var. BARI-8 & 114 & 82 & 71.93 & \\
B. campestris var. BARI-14 & 110 & 79 & 71.82 & \\
B. carinata & 101 & 69 & 68.32 & \\
\hline
\end{tabular}

Dendrogram produced by UPGMA method was distributed among 11 Brassica germplasm. There was a total of 10 clusters $(1-10)$ present in the dendrogram (Fig. 2). All the germplasm was grouped into two major branches $\left(\mathrm{B}_{1}\right.$ and $\left.\mathrm{B}_{2}\right)$. The germplasm Brassica carinata (also called Ethiopian mustard) formed a separate branch $\left(\mathrm{B}_{2}\right)$, which was totally different from other 10 Brassica germplasm of Bangladesh. Another 10 germplasm of Brassica clustered in $\mathrm{B}_{1}$ that is divided into two sub-branches. BARI-13 and BARI-8 were clustered in cluster No.6 that was present in sub-branch-1 $\left(\mathrm{SB}_{1}\right)$. $\mathrm{SB}_{2}$ divided into several clusters. Cluster number 8 was originated from $\mathrm{SB}_{2}$ and these clusters contain another 6 clusters $(1,2,3,4,5$ and 7). Two germplasm of Brassica juncea (BARI-11 and BARI-16) formed cluster number 2 (Fig. 2). Cluster No. 7 contains six germplasm of Brassica campestris (Safal, Agrani, Bina-6, BARI-15, Tori-7 and BARI-14). From genetic distances matrix (Table 3), it was observed that these five germplasm showed low genetic distances among them in a ranging from $0.0468-0.2860$. Thus, there was a clear clustering pattern of geographically closer germplasm in the present study indicating that the association between genetic similarity and geographical distance has significance.

Based on the ISSR profiling, a comparative study of acid phosphatase, peroxidase and esterase isozymes was carried in order to characterize 10 germplasm of Brassica spp. (Fig. 3 a,b). Along with 9 other Brassica germplasm, Brassica campestris var. Agrani was selected for isozyme analysis between Brassica campestris var. Agrani and Brassica campestris var. Binasarisha- 6 as their genetic distance was very low i.e. 0.0468. Zymogram for acid phosphatase 
displayed eight distinct activity zones (Fig. 3 c,d). Zymotype 'A' occurred most frequently $(28.571 \%)$ followed by other types. On the other hand, peroxidase zymogram exhibited 7 zymotypes with highest frequency on 'E' type which is $40.0 \%$ (Fig. 3). Zymotype frequency for each enzyme activity was listed in Table 5. Esterase zymotype formulated total 33 bands (Fig. 3)

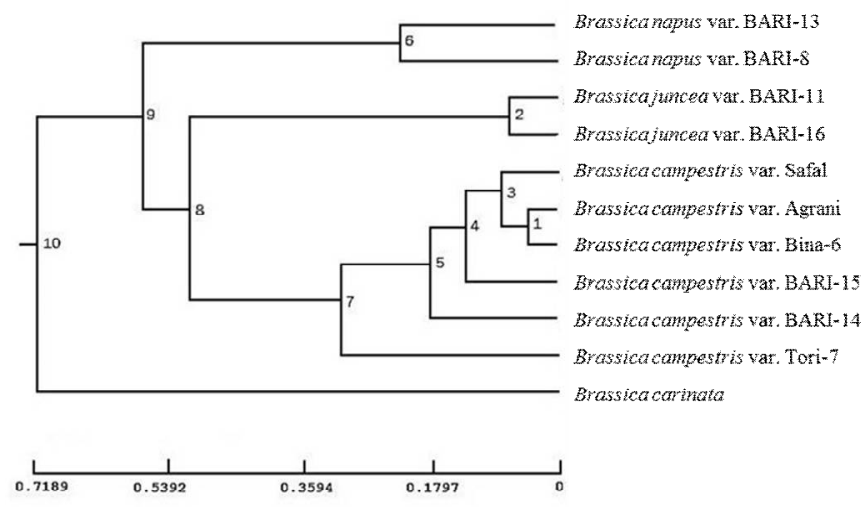

Fig. 2. UPGMA dendrogram constructed based on Nei's genetic distance summarizing the data on differentiation among Brassica germplasm by ISSR analysis.
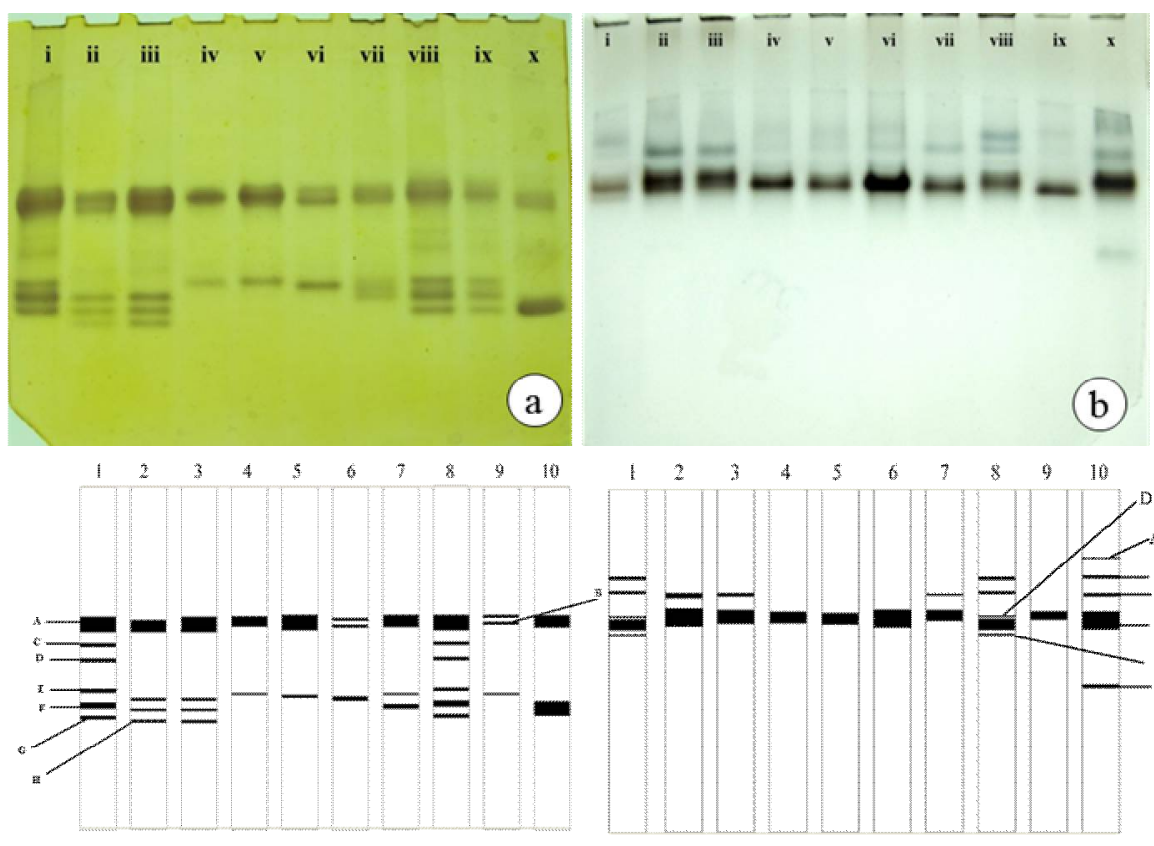

(c)

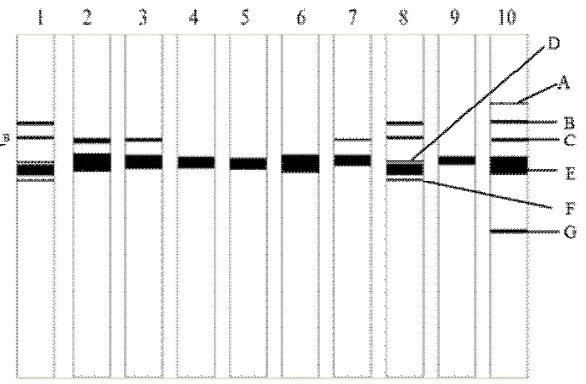

(d)

Fig. 3. Isozyme activity of 10 Brassica germplasm on polyacrylamide gel. (a) Activities of acid phosphatase enzyme. Lane - i - x. (i) Brassica napus var. BARI-13, (ii) Brassica juncea var. BARI-11, (iii) Brassica juncea var. BARI16, (iv) Brassica campestris var. Safal, (v) Brassica campestris var. Agrani, (vi) Brassica campestris var. BARI-15, (vii) Brassica campestris var. Tori-7, (viii) Brassica napus var. BARI-8 (ix) Brassica campestris var. BARI-14, (x) Brassica carinata, respectively. (b) Same as (a) but for the enzyme peroxidase. (c) Zymogram for 10 germplasm of Brassica for acid phosphatase. (d) Zymogram for peroxidase enzyme activity. Order of the samples are same as (a) in (c) and (d). 
with highest zymotype frequency of $27.27 \%$ by 'J' type band among 10 distinct zymotypes. Esterase enzyme activity produced highest number of zymotype which indicate a wide variation and could be used as genetic markers to estimate the genetic diversity according to Nakagahra (1977).

Isozyme expressions are almost exclusive of the genetic makeup of the plant and therefore, independent of environmental conditions (Schwartz 1960, Lee and Ronalds 1967). According to Ivy et al. (2010), zymotype of higher frequency are the representative of less variation. The lower frequency of the germplasm in different zymotypes indicated higher variation among the germplasm. In the present study, acid phosphatase, peroxidase and esterase isozymes were separated by electrophoresis to reveal the isozymatic variation among ten different germplasm of Brassica in relation to seed color, disease resistance and stress tolerance.

Brassica carinata or Ehiopian mustard generated exclusive bands in all the three enzyme systems. This information may help one to conclude that the germplasm of Brassica from Bangladesh differ in their isozymetic types from Ethiopian mustard (Brassica carinata) as it has several unique traits such as resistance to drought (Kumar et al. 1984), pod shattering, disease resistance (Alonso et al. 1991) and grows better under saline and late-sown conditions (Malik 1990). According to Majumder et al. (2012), the results generated with isoenzyme study will be helpful in improvement as well as may guide one in designing strategies that maximize the utility of genetic resources.

Table 5. Frequency (\%) of zymotypes for 3 enzyme systems.

\begin{tabular}{|c|c|c|c|c|c|}
\hline \multicolumn{2}{|c|}{ Acid phosphatase } & \multicolumn{2}{|c|}{ Peroxidase } & \multicolumn{2}{|c|}{ Esterase } \\
\hline Zymotype & Frequency & Zymotype & Frequency & Zymotype & Frequency \\
\hline A (10) & 28.571 & A (1) & 4.0 & $\mathrm{~A}(1)$ & 3.03 \\
\hline B (2) & 5.714 & B (3) & 12.0 & B (3) & 9.09 \\
\hline $\mathrm{C}(2)$ & 5.714 & C (6) & 24.0 & C (3) & 9.09 \\
\hline $\mathrm{D}(2)$ & 5.714 & $\mathrm{D}(2)$ & 8.0 & $\mathrm{D}(2)$ & 6.06 \\
\hline E (7) & 20.000 & E (10) & 40.0 & E (5) & 15.15 \\
\hline $\mathrm{F}(6)$ & 17.143 & $\mathrm{~F}(2)$ & 8.0 & $\mathrm{~F}(3)$ & 9.09 \\
\hline G (4) & 11.428 & G (1) & 4.0 & G (1) & 3.03 \\
\hline \multirow[t]{3}{*}{ H (2) } & 5.714 & & & H (3) & 9.09 \\
\hline & & & & I (3) & 9.09 \\
\hline & & & & J (9) & 27.27 \\
\hline
\end{tabular}

A dendrogram representing 10 Brassica germplasm was constructed by UPGMA analysis (Fig. 4) based on three kinds of polymorphic isoenzyme activities. All the 10 germplasm were grouped into two major branches $\left(\mathrm{B}_{1}\right.$ and $\left.\mathrm{B}_{2}\right)$. Brassica carinata formed a separate branch $\mathrm{B}_{2}$ from all the nine BARI and BINA germplasm which are clustered in $B_{1} . B_{2}$ is divided into two subbranches, $\mathrm{SB}_{1}$ and $\mathrm{SB}_{2}$. BARI-13 and BARI- 8 were clustered in cluster number 3 that was present in sub-branch $1\left(\mathrm{SB}_{1}\right)$. Two germplasm of Brassica juncea (BARI-11 and BARI-16) formed cluster number 1 (Fig. 4). Cluster number 1 and cluster number 6 together produce cluster number $7\left(\mathrm{SB}_{2}\right)$. Cluster number 5 contains all the yellow seeded germplasm of Brassica campestris (Safal, Agrani, BARI-15 and BARI-14). Brassica campestris var. Tori-7 formed a separate branch from 
all the yellow seeded Brassica campestris. This phylogenetic analysis based on the isozymetric analysis is in harmony with the ISSR analysis, which revealed the relatedness among the germplasm.

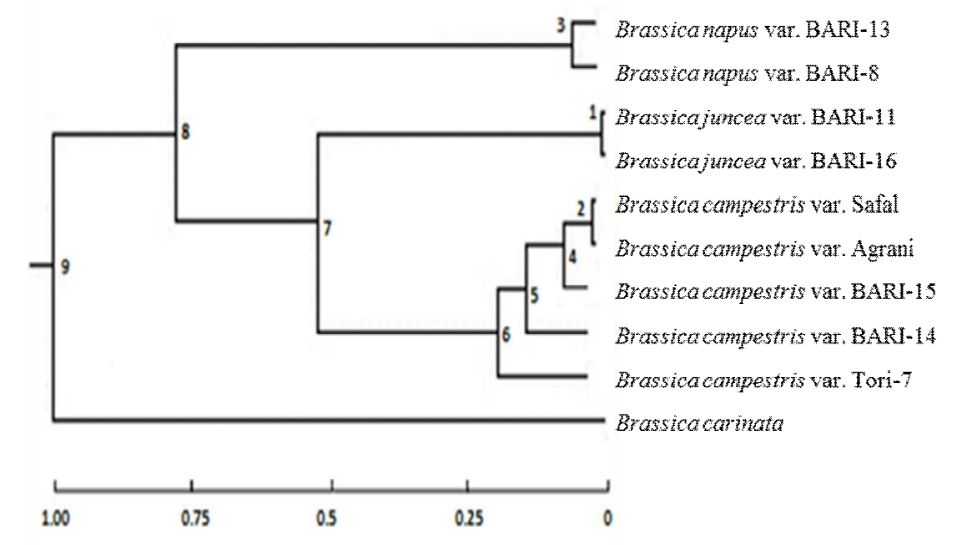

Fig. 4. Dendrogram constructed based on genetic distance summarizing the data on differentiation among Brassica germplasm by isozyme activity analysis.

The distribution of Brassica germplasm in dendrogram showed their broad genetic base for the marker assisted and isozymetic studies. Closely resembling as well as distinct Brassica germplasm was identified. Both the ISSR marker assisted study and isozymetic polymorphism study indicated that Brassica carinata was highly genetically diverse from most of the germplasm studied in this investigation. Thus, B. carinata may be a very important resource of genetic diversity to be maintained and utilized in future breeding programmes. Additionally, the unique bands obtained for several varieties of Brassica germplasm in the ISSR study signify the power of ISSR markers in fingerprinting and genetic diversity analysis. These unique bands can be further used as variety specific marker and further be exploited in future breeding programme. Successful inter varietal crossings can be performed using these variety specific markers. Isozymetic study also revealed a high degree of genetic diversity among the germplasm examined in the study, which can contribute to the improvement of oilseed Brassica. The results of the present investigation has opened up a possibility for developing a molecular genetic map that will lead to the application of marker assisted selection tools in genetic improvement of Brassica germplasm.

\section{Acknowledgements}

The authors are grateful to Bangladesh Agricultural Research Institute (BARI), Bangladesh Institute of Nuclear Agriculture (BINA) and ACI Ltd. for providing the seeds of different germplasm of Brassica used in this study. The first author (MP) is grateful to the Ministry of Science and Technology, Govt. of the People's Republic of Bangladesh for awarding NST fellowship during this study.

\section{References}

Abou-Deif MH, Rashed MA, Sallam MAA, Mostafa EAH and Ramadan WA 2013. Characterization of 20 wheat varieties by ISSR markers. Middle-East J. Sci. Res. 15(2): 168-175.

Afiah SA, Abdelsalam AZE and Abdel-Gawad ZA 2007. Bulked segregant analysis for developing genetic markers of drought tolerance in faba bean (Vicia faba L.). Egyptian J. Desert Res. 57(1): 89-112. 
Agnihotri A, Prem D and Gupta K 2007. The chronicles of oil and meal quality improvement in rapeseed. In: Gupta, S.K. (Ed.), Advances in Botanical Research - Rapeseed Breeding. Academic Press/Elsevier Ltd., San Diego, CA, pp. 50-99.

Agrama HA and Tuinstra MR 2003. Phylogenetic diversity and relationships among sorghum accessions using SSRs and RAPDs. Afr. J. Biotechnol. 2: 334-340.

Alonso LC, Fernandez-Serrano O and Fernandez-Esrcobar J 1991. The outset of a new oilseed crop: Brassica carinata with a low erucic acid content. Proc. 8th Int. Rapeseed Congr. Saskatoon. 170-176.

Arús P and Orton TJ 1983. Inheritance and linkage relationships of isozyme loci in Brassica oleracea. J. Heredity 74(6): 405-412.

Bimb HP, Sah RP and Karn NL 2004. Isozyme variations in fine and aromatic rice genotypes. Nepal Agric. Res. J. 5: 59-66.

Bozzini A, Calcagno F and Soare T 2007. "Sincron", a new Brassica carinata cultivar for biodiesel production. Helia 30(46):207-214.

Chevre AM, This P, Eber F, Deschamps M, Renard M, Delseny M and Quiros CF 1991. Characterization of disomic addition lines Brassica napus- B. nigra by isozyme, fatty acid and RFLP markers. Theor. Appl. Genet. 81: 43-49.

Dorado MP, Ballesteros E, López FJ and Mittelbach M 2004. Optimization of alkali-catalyzed transesterification of Brassica carinata oil for biodiesel production. Energy Fuels 18: 77-83.

Doyle JJ and Doyle JL 1990. Isolation of plant DNA from fresh tissue. Focus 12: 13-15.

FAO 2010. FAO Agricultural Outlook 2010-2019.

Ghariani S, Trifi-Farah N, Chakroun M, Marghali S and Marrakchi M 2003. Genetic diversity in Tunisian perennial ryegrass revealed by ISSR markers. Genet. Resour. Crop Evol. 50: 809-815.

Ishida M, Kaoru E, Shuichi F, Makoto Y and Tsukasa N 2000. Genetic diversity in Japanese rapeseed and Swede (Brassica napus) germplasm based on RAPD markers. 3rd ISHS International Symposium on Brassica, 12th Crucifer Genetics Workshop. Sept. Horticulture Research International Wellsbourne, CV359EF, UK. pp. 5-9.

Ismail NA, Rafii MY, Mahmud TM, Hanafi MM and Miah G 2016.Molecular markers: a potential resource for ginger genetic diversity studies. Mol. Biol. Rep. 43(12): 1347-1358.

Ivy NA, Biswas MS, G. Rasul, Hossain T and Mian MAK 2010.Variations of genotypes of radish at molecular level using isozyme analysis for the identification of self-incompatible lines. Global $\mathrm{J}$. Biotech. Biochem. 5(1): 19-26.

Johnson M, Janakiraman N and Irudayaraj V 2012. Isozyme analysis on different varieties of sugarcane. J. Stress Physiol. Biochem. 8(2): 22-31.

Kimura Y, Fujimoto H, Sakai T, Imamura J, Ma CZ and Fu TD 2000.Genetic diversity of Chinese and Japanese rapeseed (Brassica napus L.) varieties detected by RAPD markers. Breed. Sci. 50: 257-265.

Kumar A, Singh P, Singh H and Sharma H C 1984. Differences in osmoregulation in Brassica species. Ann. Bot. 54: 537-541.

Lee JW and Ronalds JA 1967. Effect of environment on wheat. Nature 213: 844-846.

Long Y, Cheng J, Mei Z, Zhao L, Wei C, Fu S, Khan MA and Fu J 2015. Genetic analysis of litchi (Litchi chinensis Sonn.) in southern China by improved random amplified polymorphic DNA (RAPD) and inter-simple sequence repeat (ISSR). Mol. Biol. Rep. 42: 159-166.

Majumder DAN, Hassan L, Rahim MA and Kabir MA 2012. Analysis of genetic diversity in mango (Mangifera indica L.) using isozymetic polymorphism. African J. Biotechnol. 11(87): 15310-15323.

Malik R S 1990. Prospects for Brassica carinata as an oilseed crop in India. Exp. Agri. 26. 125-129.

Marillia EF, Francis T, Falk KC, Smith M and Taylor DC 2014. Palliser's promise: Brassica carinata, an emerging western Canadian crop for delivery of new bio-industrial oil feedstocks. Biocatalysis and Agricultural Biotechnology 3(1): 65-74.

McVetty PB, Lukow OM, Hall LM, Rajcan I and Rahman H 2016. Oilseeds in North America. Reference Module in Food Science. pp. 1-8. 
Moghaddam M, Mohammadi MS, Mohebalipour N, Toorchi M, Aharizad S and Javidfar F 2009. Assessment of genetic diversity in rapeseed cultivars as revealed by RAPD and microsatellite markers. Afr. J. Biotechnol. 8: 3160-3167.

Nakagahra M 1977. Genetic analysis for Esterase isoenzymes in rice cultivars. Jpn. J. Breed. 27(2): 141-148.

Nei M 1972. Genetic distance between populations. Amer. Nat. 106: 283-292.

Pakseresht F, Talebi R and Karami E 2013. Comparative assessment of ISSR, DAMD and SCoT markers for evaluation of genetic diversity and conservation of landrace chickpea (Cicer arietinum L.) genotypes collected from north-west of Iran. Physiol Mol. Biol. Plants. 19(4): 563-574.

Panda S, Martin JP and Aguinagalde I 2002. Chloroplast and nuclear DNA studies in a few members of the Brassica oleracea L. group using PCR-RFLP and ISSR-PCR markers: a population genetic analysis. Theor. Appl. Genet. 106: 1122-1128.

Raymer PL 2002. Canola: an emerging oilseed crop. In: Janick, J., Whipkey, A. (Eds.), Trends in New Crops and New Uses. ASHS Press, Alexandria, VA, pp. 122-126.

Sandip D, Rajagopal J, Bhatia S and Lakshmikumaran M 1999. Assessment of genetic diversity in Brassica campestris cultivars using random amplification of polymorphic DNA (RAPD) and amplified fragment length polymorphism (AFLP): comparison of the two marker technologies. J. Biosci. 24: 433-440.

Schwartz D 1960. Genetic studies on mutant enzymes in maize: synthesis of hybrid enzymes by heterozygotes. Proc. Nat. Acad. Sci. 46:1210-1215.

Shiran B, Azimkhani R, Ahmadi MR and Mohammadi S 2004. Assessment of genetic diversity among rapeseed (Brassica napus L.) cultivars using random amplified polymorphic DNA (RAPD) analysis. Proceedings of the Fourth International Iran \& Russia Conference. Moscow, Russia. pp. 20-25.

Singh KH, Shakya R, Thakur AK, Chauhan DK and Chauhan JS 2013. Genetic diversity in Indian mustard [Brassica juncea (L.) Czernj and Cosson] as Revealed by agronomic Traits and RAPD Markers. Natl. Acad. Sci. Lett. 36: 419-427.

Tanksley SD and Orton TJ 1983. Isozyme in plant genetics and breeding (Part B) Elesvier Amstardam p. 472.

Velasco L, Nabloussi A, De Haro A and Fernández-Martínez JM 2003. Development of high-oleic, lowlinolenic acid Ethiopian-mustard (Brassica carinata) germplasm. Theor. Appl. Genet. 107(5): 823-830.

Zada M, Zakir N, Rabbani MA and Shinwari ZK 2013. Assessment of genetic variation in ethiopian mustard (Brassica carinata A. Braun) germplasm using multivariate techniques. Pak. J. Bot. 45(SPL.ISS): 583-593.

Zhao J, Wang X, Deng B, Lou P, Wu J and Sun R 2005. Genetic relationships within Brassica rapa as inferred from AFLP fingerprints. Theor. Appl. Genet. 110: 1301-1314.

Zietkiewicz E, Rafalski A and Labuda D 1994. Genome fingerprinting by simple sequence repeat (SSR)anchored polymerase chain reaction amplification. Genomics 20: 176-183.

(Manuscript received on 29 April, 2019 revised on 21 July, 2019 